Revista Brasileira de Higiene e Sanidade Animal

Brazilian Journal of Hygiene and Animal Sanity

ISSN: 1981-2965

\title{
Sertolioma in a dog: Case Report
}

Sertolioma em cão: Relato de Caso

\section{Cleyson Teófilo Braga Filho ${ }^{1}$, Priscila Sales Braga ${ }^{2}$, Carlos Eduardo Bastos Lopes ${ }^{3}$,} Camila Lacerda Soares ${ }^{4}$, Daniel de Araújo Viana ${ }^{5}$

\begin{abstract}
Testicular neoplasms are more common in dogs than in other species of domestic animals. The Sertoli cell tumor is one of the most frequent testicular neoplasms, arising from specific support cells inside the seminiferous tubules. One of its major characteristics is to be able to present a benign behavior, being one of the most common tumors in non-castrated male old dogs. Generally, it does not course with clinical symptoms, appearing to be the testicular growth the first signal to start suspicions of the affection in most of the time. This work aims to report a case of Sertolioma in a 10-year-old domestic mixed breed dog.
\end{abstract}

Keywords: Canine, Neoplasia, Testicle, Histopathology, Sertoli cell tumor.

Resumo: As neoplasias testiculares são mais comuns nos cães do que em outras espécies de animais domésticos. O tumor de células de Sertoli é uma das neoplasias testiculares mais freqüentes, decorrentes de células de suporte específicas dentro dos túbulos seminíferos. Uma das principais características é poder apresentar um comportamento benigno, sendo um dos tumores mais comuns em cães idosos não castrados. Geralmente, não acontece com sintomas clínicos, aparentemente como o crescimento testicular, o primeiro sinal para iniciar a suspeita de carinho na maior parte do tempo. Este trabalho tem como bjetivo relatar um caso de Sertolioma em um cão de raça mista doméstica de 10 anos de idade.

Palavras-chave: Canino, Neoplasia, Tesículo, Histopatologia, tumor de Sertoli.

Corresponding author: cleysont@gmail.com

Recebido em 02.08.2017. Aceito em 30.09.2017

${ }^{1}$ Veterinarian - Faculty of Veterinary - State University of Ceará - Fortaleza - cleysont@gmail.com

${ }^{2}$ Undergraduate student - Faculty of Biological Sciences - State University of Ceará - Fortaleza priscilasalesbraga2@gmail.com

${ }^{3}$ Undergraduate student - Faculty of Veterinary - State University of Ceará - Fortaleza 1993carlos.eduardo@gmail.com

${ }^{4}$ Veterinarian - Faculty of Veterinary - State University of Ceará - Health Department - Crateús camyllalacerda@hotmail.com

${ }^{5}$ Postgraduate Program in Veterinary Sciences - Faculty of Veterinary - State University of Ceará Pathovet Clinical Pathology Laboratory - Fortaleza - viana.daniel78@gmail.com

htpp://dx.doi.org/10.5935/1981-2965.20170033 


\section{Introduction}

The reproductive system diseases are common in veterinary medicine, both in females and males of different species. Thereby, various diseases may cause pathological changes in the genital organs of domestic animals, being also capable of presenting different degrees of manifestation in those sites (PREVIATO et al., 2005).

The reproductive alterations may culminate in a variety of consequences. It goes from absence of clinical signs, silently compromising the fertility of the animal, which most times stays unknown by the tutor, until acute clinical manifestations, that can conduct to death. Among the male sex pathologies, the affection of testicles stands out as one of the most frequents, being possible to point out cases of cryptorchidism, atrophy, hypoplasia, degeneration, orchitis, epididymitis, torsion and neoplasms (NASCIMENTO \& SANTOS, 2003).

Testicular neoplasms are even more common in dogs, than in other species of domestic animals. They mostly affect uncastrated male dogs that, in its majority, are senile. In most of the cases, these tumors are comprehended as incidental findings (NELSON \& COUTO, 2001).
The Sertoli cell tumor is one of the most frequent testicular neoplasms, arising from specific support cells located inside the seminiferous tubules. Although the tumor type is frequent in dogs, it has also been found in stallions, cats, rams and bulls (ESLAVA \& TORRES, 2008).

Considering the great relevance of the testicular affections for the veterinary medicine and the importance of obtaining a precise diagnosis for the correct targeting of an ideal treatment, the aim of this work was to report a case of Sertolioma in a mixed breed dog in the Veterinary Hospital Sylvio Barbosa Cardoso of the State University of Ceará.

\section{Case Report}

It was presented to the Veterinary Hospital Sylvio Barbosa Cardoso of the State University of Ceará, a male uncastrated mixed breed dog, with 10 years old and $5.5 \mathrm{Kg}$.

The animal arrived in the hospital to perform a clinical evaluation and posterior scheduling for bilateral orchiectomy, by being firstly forwarded from another facility, with a previous history of enlargement of the right testicle. As prior exams, it was just provided an abdominal ultrasonography taken three days earlier. During the anamnesis, the tutor reported that all the viral vaccines and 
deworming were properly done. The animal, that used to receive daily amounts of home-made food and dry ration, had never presented before any history of serious diseases or similar complications. Besides, the dog was not allowed to have access to the street or other animals. Lastly, it was not found any alterations in its urine and feces.

During the physical exam, it was observed that the animal was alert and its mucous membranes were normally colored. In cardiac auscultation, it was observed a slight tachycardia. The dog's temperature was $39.4^{\circ} \mathrm{C}$ and it was lightly dehydrated. The capillary refill time was approximately 2 seconds long, and the body condition score had no abnormalities for its size. Yet, it was not found any external parasites or reactivity in lymph nodes. Additionally, during inspection of the right testicle, the enlargement of the organ was confirmed. In palpation, it was felt a firm consistency, with absence of discomfort or pain. When compared to the previously examined organ, the bilateral testicle (left) presented a significant reduction of its size as expected. According to the ultrasound report, the right testicle was measuring $47.0 \times 33.0$ $\mathrm{mm}$, with presence of irregular margins, together with decreased echogenicity and heterogeneous echotexture, being possible to evaluate an abundant vascularization and, therefore, making it clearer for the clinicians to suspect of neoplasm. Besides, the left testicle measured $15.0 \times 12.0 \mathrm{~mm}$, showing regular margins, with reduced dimensions, normal echogenicity and homogeneous echotexture, presenting a pattern compatible with atrophy.

After the performance and analysis of all the pre-surgical exams, the referred animal was sent for the procedure of bilateral orchiectomy. The right testicle, which was increased in size, was forwarded to the histopathological analysis.

Ten days after the surgery, the animal returned to the initial establishment to have stitches removed, where it could not be observed any inflamed stiches. Moreover, there was no presence of any visible secretion.

Two weeks after the surgery, it was obtained the biopsy results. The anatomopathological report about the surgical specimen revealed: affected testicle measuring $6.0 \times 5.0 \times 3.0 \mathrm{~cm}$, and appearing to be partially covered by segments of skin, revealing in cross section a whitish and multilobulated compact surface (Figure 01). 


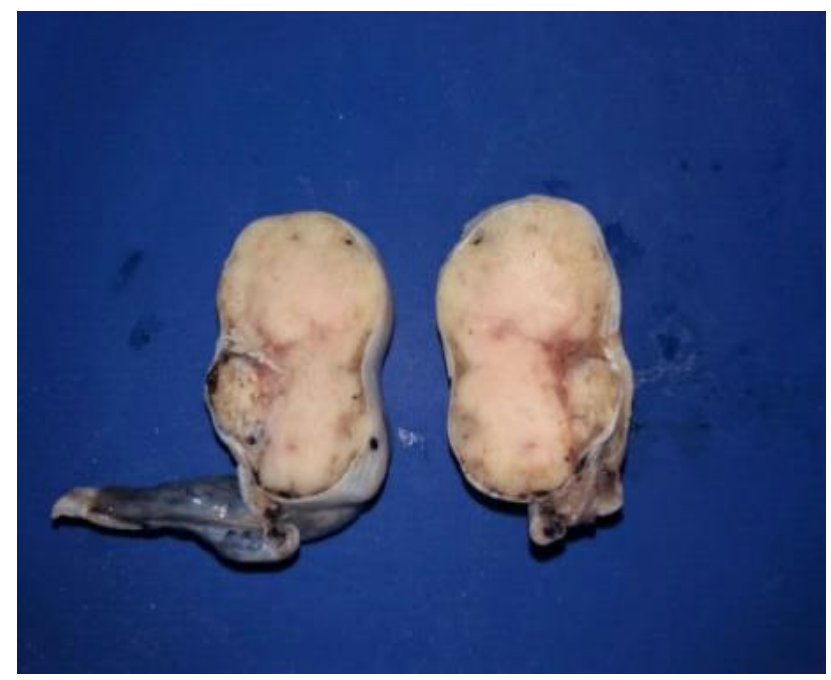

Figure 01: Cross section of the right testicle of the dog (Bob) treated at the Hospital Sylvio Barbosa Cardoso.

The histopathological sections of the testicle exhibited neoplasm reproducing Sertoli cells, by presenting moderate anisocytosis with wide cytoplasm, rounded nuclei of reticular chromatin and evident nucleoli, occupying the seminiferous tubules in almost of its totality, with additional evidence of central necrosis areas, moderate fibrosis, foci of hemorrhage and some mitotic figures (Figure 02). Then, it was concluded that the animal was presenting a histopathological condition compatible with Intratubular Sertolioma.

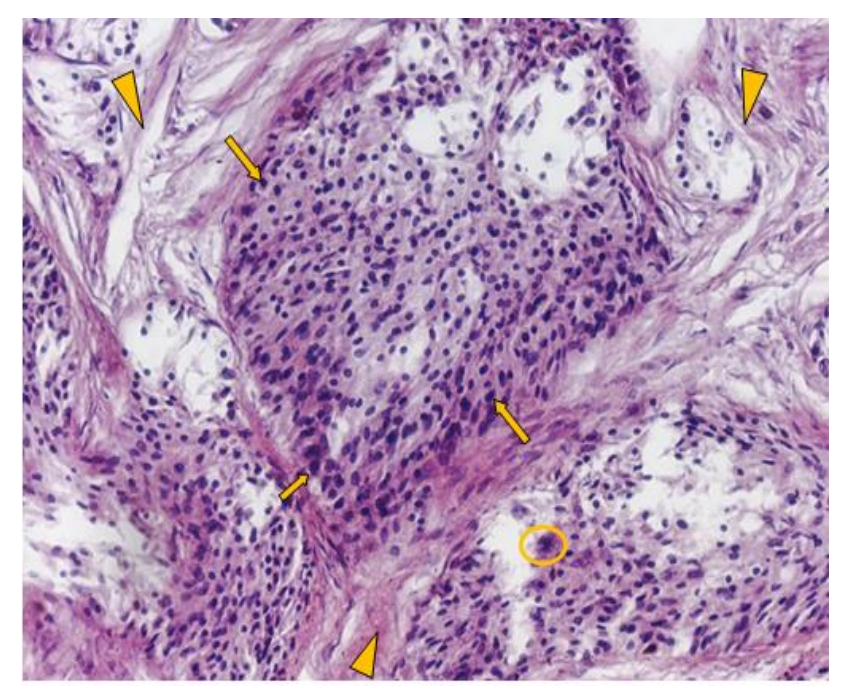

Figure 02: Details of the morphology of Sertoli cells, presenting elongated cytoplasm with oval nuclei (arrows), intertubular fibrosis (arrow heads) and mitotic figures (circle) (HE, 400X). 


\section{Discussion}

The testicular pathologies usually have a great importance in the small animal clinic. By the early recognition of the diseases, through the complete clinical or by means of any other method of diagnosis, whether through image or laboratory means, it is possible to guarantee the rapid initiation, as well as its adequacy of the treatment, assuring a greater survival of the animal (DOMINGOS \& SALOMÃO, 2011).

The animal of the present study had 10 years and was not castrated. This information confirms the data of Feldman \& Nelson (2004), because in their study, it was verified that exists a higher incidence of testicular neoplasms in non-neutered animals of a most advanced age, being the median age between 9 and 11 years old.

The dog had no defined breed, what is different of the literature, in which, according to Argyle et al. (2008), it would be more predisposed to develop testicular neoplasms the dogs of the following breeds: German Shepperd, Boxer, Weimaraner, Shetland Sheepdog, Chihuahua, Poodle, Miniature Schnauzer, Siberian Husky and Yorkshire Terrier.

For Eslava \& Torres (2008), the frequency of development of the testicular tumors is thirteen times higher when one or both testicles are retained in the abdominal cavity, but in this study, it was verified that the neoplasm was actually found in the scrotum. Additionally, it was observed that the right testicle was the one affected, as it was refereed by Morris \& Dobson (2001), in which it was defended a higher prevalence for this testicle, in contrast to the contralateral organ (left testicle).

As mentioned by Choi et al. (2008), about $20-30 \%$ of the Sertoli cell tumors can be hormonally active and the dogs may present the feminization syndrome. However, accordingly to McEntee (2002), in most cases the animals affected by the testicular neoplasms are asymptomatic, what was compatible to the case in study.

In the present case, it was chosen to be performed the ultrasound exam to mainly evaluate the testicles of the animal, such as to verify the organs of the abdominal cavity. The ultrasonography is a safe and accurate diagnostic tool, useful for evaluation, detection and monitoring of the testicular affections in dogs by enabling the analysis of the location, outlines, form and volume, besides echotexture and parenchymal echogenicity, presence of cystic structures, abscedations and mineralizations (FELICIANO et al., 2013).

According to Carvalho (2004), the ultrasonographical aspect of the testicular neoplasms is variable and non-specific. Large injuries generally present a mixed or complex parenchymal pattern, that may be secondary to hemorrhage and necrosis. The tumors may also cause generalized testicular enlargement and obliteration of the testicular mediastinum and epididymis. Still about the exam possible findings, it is expected to find focal and 
multifocal lesions, which may be hypo or hyperechoic. In the present case, the right testicle of the animal presented an increase in volume, irregular margins, decreased echogenicity and heterogeneous echotexture, besides the presence of an abundant vascularization, only visualized by the Doppler method.

In this way, the use of the color Doppler may help in the establishment of differential diagnosis of the intratesticular masses, mostly to exclude the suspect of orchitis (DE DIEGO et al., 2003). The testicular tumors higher than $3 \mathrm{~cm}$ tend to be more vascularized than the ones smaller, although there are no doppler fluxometric parameters that can be used in the daily practical medicine by the sonographer (Woodward et al., 2002). Yet, some authors affirm that it can be identified a drop in the resistance index or an increase in the peak of the systolic speed of the affected testicle, due to the tumoral neoangiogenesis (DOGRA et al., 2004).

The left testicle was presenting itself with a much lower volume than the right, its contralateral organ, evidencing habitual echogenicity and homogeneous echotexture. In the ultrasound examination, both the decrease of the size and isoechoic (normal) or hypoechoic parenchyma have been described in cases of testicular atrophy (NYLAND \& MATTOON, 2002). These data are compatible with the work of Feldman \& Nelson (2004), in which, having the presence of a unilateral tumor, it could be noted a testicular asymmetry, observing an atrophy in the contralateral testicle.
It was performed the bilateral orchiectomy, with total ablation of the scrotum, that, according to the majority of the authors, is the treatment of election for this kind of neoplasia, also being usually curative (MCENTEE, 2002; FAN \& LORIMIER, 2007). Generally, the testicular neoplasms are not aggressive biologically, being the orchiectomy a therapeutic measure of potential use.

According to Feldman \& Nelson (2004), the histologic confirmation of a testicular neoplasia is the major manner to confirm the diagnosis. Thereby, in agreement to what is recommended by the literature, the oversized testicle was sent for histopathological analysis, confirming the diagnosis of Sertoli cell neoplasm or Sertolioma. Then, the macroscopic description of the tumor matches with what was related in the work of Kennedy \& MacLachlan (2002), by having the tumor presenting, in cross section, a compact, multilobulated and whitish surface.

The microscopic description of the data, corroborated with what was described by Masserdotti et al. (2005), about the Sertolioma in its intratubular form, presenting Sertoli cells of moderate anisocytosis with wide cytoplasm, oval nuclei of reticular chromatin and evident nuclei that occupy the seminiferous tubules, in almost of its totality.

\section{Conclusion}

It has been verified that testicular tumors can also appear, with some frequency, in non-cryptorchid dogs as in mixed breed dogs.

For most cases, dogs affected by testicular 
neoplasms are asymptomatic. Moreover, in this study, it was not observed the feminization syndrome. Finally, imaging exams, such as the ultrasonography, are important tools for the evaluation of the reproductive tract of male dogs, being possible to suggest pathologies in a noninvasive approach, even knowing that the histopathological exam remains as the main method of choice when talking about closing the case.

\section{References}

1. ARGYLE, D.; BREARLEY, M.J.; TUREK, M.M. Decision Making in Small Animal Oncology. cap. 3. p. 45-50. Iowa: Wiley Blackwell. 2008.

2. CARVALHO, C.F. Ultrassonografia em pequenos animais. São Paulo: Roca, 2004. 365p.

3. CHOI, U., KIM, H., CHOI, J., KIM, H., JANG, J., LEE, C. Sertoli Cell Tumor Accompanied by Pancytopenia in a Dog. Journal of Veterinary Clinics., v.25. Coreia, 2008.

4. DE DIEGO, A.C.; LÓPEZ, R.G.; HERNÁNDEZ, R.R.; MARCOS, L.E.; LASTRA, G.P.; HERNÁNDEZ, C.A. Lesiones testiculares que no hay que tocar. Arch Esp Urol., v.56, p. 255-266, 2003.

5. DOGRA, V.S.; RUBENS, D.J.; GOTTLIEB, R.H.; BHATT, S. Torsion and beyond. Journal Ultrasound Med., v.23, p.1077-1085, 2004.

6. DOMINGOS, T.C.S.; SALOMÃO, M.C. Meios de diagnóstico das principais afecções testiculares em cães: revisão de literatura. Revista Brasileira de Reprodução Animal, v.35, n.4, p.393-399, 2011.

7. ESLAVA, P. TORRES, G. Neoplasias testiculares en caninos: un caso de tumor de células de Sertoli. Revista MVZ. Córdoba v.13, p.1215-1225.Córdoba. 2008.

8. FAN, T.M.; LORIMIER, L. Tumors of the male Reproductive System. In: WITHROW, J.S; MACEWEN. E.G.(Eds). Withrow and MacEwen's Small Animal Clinical Oncology. 4. ed., p. 637-641. St.Louis: Saunders Elsevier. 2007.
9. FELDMAN, E.C.; NELSON, R.W. Disorders of the Testes and Epidymides. In E. C. FELDMAN.; R. W. NELSON (Eds.), Canine and Feline Endocrinology and Reproduction. 3. ed., p. 961 977. St. Louis Missouri: WB Saunders Co, 2004.

10. FELICIANO, M.A.R., OLIVEIRA, M.E.F., VICENTE, W.R.R., Ultrassonografia na reprodução animal. São Paulo: Med Vet, 191 p. 2013.

11. KENNEDY, P.C.; MACLACHLAN, N.J. Tumours of the Genital Systems. In D. J. Meuten (Ed.), Tumors in Domestic Animals. 4ed., p.547575. Iowa: Blackwell, 2002.

12. MASSERDOTTI, C.; BONFANTI, U.; DE LORENZI, D.; TRANQUILLO, M.; ZANETTI, O. Cytologic features of testicular tumours in dog. Journal of Veterinary Med A Physiol Pathol Clin Med., v.52, p.339-346, 2005.

13. McENTEE, K. Scrotum, spermatic cord and testis: proliferative lesions. Reproductive Pathology of Domestic Mammals., p.279-306. San Diego, CA: Academic Press, 1990.

14. MORRIS, J., DOBSON, J. Small animal oncology. Oxford: Blackwell Science., p.174-177, 2001.

15. NASCIMENTO, E.F.; SANTOS, R.L. Patologia da reprodução dos animais domésticos. Rio de Janeiro: Guanabara Koogan, 108p, 2003.

16. NELSON, R.W.; COUTO, C.G. Fundamentos de medicina interna de pequenos animais. 2.ed. Rio de Janeiro: Guanabara Koogan, p.716-717, 2001.

17. NYLAND, T.G.; MATTOON, J.S. Veterinary diagnostic ultrasound., 2.ed. Philadelphia: W.B. Saunders, 2002. 461p.

18. PREVIATO, P.F.G.P.; NETO, A.P.; WERNER, P.R.; ACCO, A.; MOTA, M.F.; SILVA, A.V.; FONSECA, J.F. Alterações morfológicas nos órgãos genitais de cães e gatos provenientes de Vilas Rurais da região de Umuarama-PR. Arq. ciên. Vet. Zool., v.8, p.105-110, 2005.

19. WOODWARD, P.J.; SOHAEY, R.; O'DONOGHUE, M.J.; GREEN, D.E. Tumors and tumor like lesions of the testis radiologic-pathologic correlation. Radiographics., v.22, p.189-216, 2002. 